\title{
Teachers' Expressions in EFL Classrom at a Senior High School
}

\author{
Humaeroah \\ maehumaeroah@yahoo.co.id \\ Graduate Program \\ State University of Makassar, Indonesia
}

\begin{abstract}
Expression is one of the way people communicate with others deals with exploring feeling, meaning, idea, and suggestion by using verbal or non-verbal communication. The objectives of the research are to find out (1) types of Expressions uttered by teachers, (2) the dominant expressions uttered by teachers, and (3) the students' responses toward teachers' expressions. This research employed descriptive quantitative research design. This research took two English teachers and two classes of students in SMA Neg 11 Pinrang as the participants of the research which were taken through purposive sampling. The data of this research were collected by classroom observation, video recording and interview. The research findings show that (1) there are eight expression which uttered by teachers based on Alfaro's classifications, they are greetings/farewells, spontaneous reaction, getting student's attention, telling students to do something, encouraging expressions, organizing contents, time, and places, showing sympathy, checking students' understanding, (2) telling student's to do something is the mostly expressions uttered by teachers, (3) the students responses toward teachers' expressions categorized into into two kinds, they are positive and negative response. Most of students gave positive responses on greetings, spontaneous reaction and encouraging expressions by giving feedback, doing teacher's instruction and feeling happy if the teachers uttered those expressions. Some of the students gave negative responses on the other expressions uttered by the teachers by ignoring their teacher expressions.
\end{abstract}

Keywords: Teachers' expressions, expressions of Alfaro's classifications, students' response.

\section{INTRODUCTION}

In the classroom interaction, specifically for the English subject the teacher use English in each learning stage. In measuring how the effectiveness of the interaction between teacher and student in the classroom, we can see how far the students can give response to the teachers' talk. When the students give the appropriate response toward the teachers talk, it is mean that they has been understanding the language that teachers talk.

Tudor (1993) stated that become supplier of knowledge is the main role of the teacher in the traditional modes of teaching. Not only become supplier of knowledge but also the teacher is a model for their students in classroom. Another consideration is from Nunan (1993:189) suggested that teacher talk is of crucial importance, not only for the organization of the classroom but also for the process of acquisition. Automatically in the classroom interaction, student will listen and accept all language from their teacher. 
Therefore, the teacher as the key factor in educational word should use suitable language (teachers talk) in order to making interaction effectively. In measuring how good the teachers promote their talk, we can see how the effectiveness of the interaction can facilitate learning and promote communicative interaction in the classroom activity.

As a main focus in this research, the researcher considers about teacher's talk that has many expressions with each function that teacher used in EFL classroom that teacher used as a tool of communication in the classroom. Based on the rational explanation above, the researcher would like to formulate research question as follow: 1 . What types and functions of expressions does teacher uttered in EFL classroom? 2. What are the dominant types of expressions uttered by teacher in EFL classroom? 3. How do the students respond to teachers' expressions in EFL classroom?. The result of the research was expected to give the theoretical and practical contribution for the teacher in the teaching English as a foreign language in the school.

\section{REVIEW OF LITERATURE}

\section{Nature of Language}

According to Meriams Webster dictionary, language is the system of words or signs that people use to express thoughts and feelings to each other. While, Another definition from Walija (1996:4), states that the language is the most complete and effective way to convey ideas, messages, intentions, feelings and opinions to others. From the definitions, the researcher concluded that the language is a crucial part of communication that people used in order to express their feeling, ideas, percepetions and understanding to others people in social life.

\section{English Language Expressions}

English expressions is one aspect of communication that influences someone to express feeling, ideas, wish, or a desire to do something, negotiations, solving problems, getting knowledge, building social relationship and friendship (Yoshida, 2011). The ability in using some expressions can be used to see that the people are able to speak and express their mind to interact other.

Every language has their own function in different ways including English. Kistono et al.(2006), Wardiman et al. (2008) in their books present some of the ways people use English expressions.

\section{Teacher talk}

Rod Ellis (1985) has formulated his own view about teacher talk: "Teacher talk is the special language that the teachers use when addressing L2 learners in the classroom. The teacher must consider about good teacher talk as one of crucial thing in increasing effective teaching and learning process. "Good teacher talk" should be judged by how effectively it was able to facilitate learning and promote communicative interaction in the classroom. 


\section{Teacher's Expressions}

David Barros Alfaro (2009) in his article states the classifications of expressions that teachers' uttered in the classroom. All the expressions are classified into eight expressions:

1) Greetings and farewells

2) Spontaneous reactions

3) Getting student's attention

4) Telling students to do something ( not to do something)

5) Encouraging expressions

6) Organizing contents, time and places

7) Showing sympathy

8) Checking student's understanding

\section{Student response toward teacher expressions in classroom interaction}

Based on the influence to teaching and learning process, Borich (1996) has divided response into two types or kinds of response:

a) Desired response (Positive response) : the response is desired by the teacher since it can support the teaching and learning process.

b) Undesired response (Negative response) : the response is not desired by teacher since the response can destruct the teaching and learning process or the response is not related to the teaching and learning process.

\section{METHOD}

Dealing with the proposed from research questions, the researcher employed a descriptive quantitative method in collecting and describing the data. Descriptive research aimed to get the description about types and functions of Expressions uttered by teachers in EFL classroom and the student's response toward every instruction or process in language classroom. Quantitative method used to know the percentage of expressions uttered by the teachers in SMA Neg.11 Unggulan Pinrang. The data was collected by observation classroom, video recording, and interview.

In analyzing the data from classroom observation and interview, the researcher used descriptive quantitative method which is consists of three stages: data reduction, data display and conclusion drawing/verifications. The researcher described the interaction based on the recording and then classified to find the types and the functions of teachers' expressions and also explored the students' response through the data from interview. The result of frequencies and percentage was used to describe the dominant expressions uttered by the teachers.

\section{FINDINGS AND DISCUSSION}

\section{Findings}

\section{Types and functions of Expressions Uttered by the Teachers'}




\section{1) Greetings}

Greeting is the first type of expression found by the researcher in presenting the data. This type was used by the teacher in the beginning of the class. Usually in that situation, the base primary language used in the classroom setting was Indonesian and Arabic as Muslim then said greeting in English. As the following extracts:

\section{Extract:}

T : AssalamuAlaikum warahmatullahi wabarakatuh

Ss : Waalaikumsalam warahmatullahi wabaraakatuh

$\mathrm{T}$ : see you again, in this room, in this class

Data Display:

\begin{tabular}{|l|l|l|l|}
\hline $\begin{array}{l}\text { Teacher's } \\
\text { expression } \\
\text { (extract) }\end{array}$ & Function & $\begin{array}{l}\text { Type of } \\
\text { expression }\end{array}$ & Aim/Purpose \\
\hline $\begin{array}{l}\text { AssalamuAlaiku } \\
\mathrm{m} \\
\text { warahmatullahi } \\
\text { wabarakatuh }\end{array}$ & $\begin{array}{l}\text { To greet the } \\
\text { students }\end{array}$ & Greetings & $\begin{array}{l}\text { Build positive atmosphere at } \\
\text { the beginning of the class }\end{array}$ \\
\hline
\end{tabular}

Analysis of extract

In extract one above, the teacher gave greetings by saying "Assalamualaikum warahmatullahi Wabarakatuh" and then she continued by saying "see you again". Based on the situation, the teacher's expression has function to greet student and also to start the teaching and learning process.

\section{2) Spontaneous reaction}

Spontaneous reaction is the second types of expression based on Alfaro's classification. This expression is used when suddenly the teacher gives some reactions (verbal). Sometimes, it doesn't have any relation with the context of the lesson or material during teaching and learning in the classroom such as thanking, congratulation, and checking student's body feeling, etc. As stated in the following extract:

\section{Extract}

T : okay, thank you.

Okay clap hand for us!!!

Ss : (students clap hands)

Data Display:

\begin{tabular}{|l|l|l|l|}
\hline $\begin{array}{l}\text { Teacher's } \\
\text { expression (extract) }\end{array}$ & Function & Type of expression & Aim/Purpose \\
\hline thank you & $\begin{array}{l}\text { To give thanking to } \\
\text { the students }\end{array}$ & $\begin{array}{l}\text { Spontaneous } \\
\text { reaction }\end{array}$ & $\begin{array}{l}\text { As a reward for } \\
\text { student's good } \\
\text { work }\end{array}$ \\
\hline
\end{tabular}


Analysis of Extract:

In the extract above,the teacher gave expressions to the students by saying "thank you" and continued by saying "okay clap hand for us" then student respond by clapping hand. Based on this situation, the function of the teachers' expression is to give thanking to the student because they had finished all the group performance

\section{3) Getting student's attention}

During the teaching and learning process, the teacher tries to get student's attention usually when teacher talks in front of the class so teacher can stay focus on teaching. Because sometimes, in the classroom got under control situation such as noisy and unfocused students. As the following extract:

\section{Extract :}

$\mathrm{T} \quad$ :Ssstt...Listen..Listen. (the student will mention his answer)

S : Sorry I can't go with you.

$\mathrm{T}$ : okay, perhatikan duluh..pay attention to the whiteboard!!! Dengar..disini sudah ada contoh receiving and refusing. Yaa..yang ini agak mirip-miripji semua. Ada contoh lain ketika mau menerima permintaan atau ajakan?

Data Display:

\begin{tabular}{|l|l|l|l|}
\hline $\begin{array}{l}\text { Teacher's expression } \\
\text { (extract) }\end{array}$ & Function & Type of expression & Aim/Purpose \\
\hline Listen, pay attention & $\begin{array}{l}\text { To ask student to } \\
\text { give attention to the } \\
\text { whiteboard }\end{array}$ & $\begin{array}{l}\text { Getting students' } \\
\text { attention }\end{array}$ & $\begin{array}{l}\text { In order to } \\
\text { students focus } \\
\text { to the } \\
\text { whiteboard }\end{array}$ \\
\hline
\end{tabular}

Analysis of Extract:

In the extract above, the teacher tried to get student attention by saying "Listen..Listen" then she continued by saying "perhatikan duluh..pay attention to the whiteboard!!! Dengar" and student responded it by focus on the whiteboard. In the situation above, the teacher uttered the expression to ask the student to give attention to the whiteboard when the student was too noisy while teacher explained something about the lesson.

\section{4) Telling student's to do something}

In the teaching and learning process teacher gives some command to the student in order to make the learning process effectively whether to telling about something that relate with the context of the lesson or to managing their student to be more active in the classroom. As the following extracts:

\section{Extract:}

T: Hhehe itu terserah..Okay (the teacher writes on the whiteboard). Ya.. tadi itu sudah ada satu respon untuk receive. Example? Imma, what do you say just know? Can you repeat? 
ELT Worldwide Vol. 4 No. 1 (2017)

Humaeroah: Teachers' Expressions in EFL Classrom ...

Data Display:

\begin{tabular}{|l|l|l|l|}
\hline $\begin{array}{l}\text { Teacher's expression } \\
\text { (extract) }\end{array}$ & Function & $\begin{array}{l}\text { Type of } \\
\text { expression }\end{array}$ & Aim/Purpose \\
\hline Can you repeat? & $\begin{array}{l}\text { To ask student } \\
\text { to repeat her } \\
\text { answering }\end{array}$ & $\begin{array}{l}\text { Telling students } \\
\text { to do something }\end{array}$ & $\begin{array}{l}\text { Student can repeat } \\
\text { the answer correctly }\end{array}$ \\
\hline
\end{tabular}

Analysis of extract:

In the extract above shows when teacher asked one student by saying "Imma, what do you say just know? Can you repeat?" then student respond it by answering. Based on the situation, the researcher stated that the function of the expression used by teacher above was to asking student to repeat her answering

\section{5) Encouraging expressions}

During teaching and learning process teacher should be use encouraging expression as a reward for student to build positive interaction between teacher-student and also it can get positive atmosphere in the classroom. In order that, by this expression, the students can feel the result of what they have been done as well. As following extract:

$\mathrm{T} \quad$ : Okay, I think enough for your groups..ya good presentation

Good Job..thank you ....

Data Display:

\begin{tabular}{|l|l|c|l|}
\hline $\begin{array}{l}\text { Teacher's expression } \\
\text { (extract) }\end{array}$ & Function & Type of expression & Aim/Purpose \\
\hline Good reason & $\begin{array}{l}\text { To give } \\
\text { compliment to } \\
\text { the student }\end{array}$ & $\begin{array}{c}\text { Encouragi } \\
\text { ng expression }\end{array}$ & $\begin{array}{l}\text { Student can feel a } \\
\text { reward for answered } \\
\text { the question detailed } \\
\text { and correctly }\end{array}$ \\
\hline
\end{tabular}

\section{Analysis of extract}

The extract above shows the situation when the student has finished their presentation then the teacher say "...good presentation, Good Job..thank you. Based on the situation, the expression above has function to give compliment to the student as a reward for the students' best presentation

6) Organizing contents, time and places

Organizing contents, time and places are types of expressions which is usually uttered at the beginning of the class, during the teaching and learning process, and closing the class.

Those expressions are used by teacher when the teachers want to organize the content of the class, such as to starting the material, checking student attendance and also asking about the date and day at the time as the following extracts. 
ELT Worldwide Vol 4 No 1 (2017)

Humaeroah: Teachers' Expressions in EFL Classrom ...

\section{Extract:}

$\mathrm{T}$ : Okay, today we will study about one material. One expression.Ini tentang, how to receive and refuse invitation or offering. Okay, Irma? Do you join math Olympiad? Who ask you to join it?

S : Qalby

Data Display:

\begin{tabular}{|l|l|l|l|}
\hline $\begin{array}{l}\text { Teacher's expression } \\
\text { (extract) }\end{array}$ & Function & Type of expression & Aim/Purpose \\
\hline $\begin{array}{l}\text { today we will study } \\
\text { about one material }\end{array}$ & $\begin{array}{l}\text { to tell student about } \\
\text { the material that } \\
\text { will be taught by } \\
\text { the teacher }\end{array}$ & $\begin{array}{l}\text { Organizing contents, } \\
\text { time and places. }\end{array}$ & $\begin{array}{l}\text { Student get ready } \\
\text { to receive the } \\
\text { material }\end{array}$ \\
\hline
\end{tabular}

Analysis of extract

In extract above, the situation was when the teacher informed the students about what materials that they will be learned by saying "today we will study about one material. One expression. Ini tentang, how to receive and refuse invitation or offering". In that condition, this expressions has function to tell student about the material that will be taught by teacher at the beginning of the class. In order to the students were ready to study and had a information before they discuss more about the material.

7) Showing sympathy

Showing sympathy is one of expressions such as a kinds of supporting their student during teaching and learning process. Teacher should give a sympathy expressions in order to the student feel enjoyable and being motivating in the classroom as the following extract.

\section{Extract:}

T : Apa kumis?

$\mathrm{S}$ : Mustache..

$\mathrm{T}$ : Once again! Follow Annas

$\mathrm{S}$ : repeat after me, mustache

Data Display:

\begin{tabular}{|l|l|l|l|}
\hline $\begin{array}{l}\text { Teacher's expression } \\
\text { (extract) }\end{array}$ & Function & Type of expression & Aim/Purpose \\
\hline Once again & $\begin{array}{l}\text { To ask the } \\
\text { student to } \\
\text { repeat the } \\
\text { answer }\end{array}$ & Showing sympathy & $\begin{array}{l}\text { Student use a chance to } \\
\text { pronounce word correctly } \\
\text {. }\end{array}$ \\
\hline
\end{tabular}

\section{Analysis of extract}

The extract above shows when the teacher listened mispronunciation of word from the student, so they asked one student to repeat again by saying "once again" and all students followed him. Based on the situation, the function of the extract was to ask the student to repeat the answer. 


\section{8) Checking students' understanding}

Usually, in teaching and learning process, the teachers do checking student's understanding about the material by using expressions. It's very important to be aware about student understanding about the lesson, in order to know the aim of the meeting is reached or not. The expressions as the following extract:

\section{Extract:}

$\mathrm{T}$ : okay, preparation in analytical exposition and recommendation in hortatory exposition. What's the different?

$\mathrm{S} \quad$ : In hortatory exposition give a saran mam

\begin{tabular}{|c|l|l|l|}
\hline $\begin{array}{c}\text { Teacher's } \\
\text { expression (extract) }\end{array}$ & \multicolumn{1}{|c|}{ Function } & \multicolumn{1}{c|}{$\begin{array}{c}\text { Type of } \\
\text { expression }\end{array}$} & \multicolumn{1}{c|}{ Aim/Purpose } \\
\hline $\begin{array}{c}\text { What's the } \\
\text { different? }\end{array}$ & $\begin{array}{l}\text { To ask the students } \\
\text { to mention the } \\
\text { different of the text }\end{array}$ & $\begin{array}{l}\text { Checking } \\
\text { student's } \\
\text { understanding }\end{array}$ & $\begin{array}{l}\text { The teacher knows } \\
\text { whether the student } \\
\text { can differentiate the } \\
\text { kinds of the text or } \\
\text { not }\end{array}$ \\
\hline
\end{tabular}

Analysis of the extract

The extract above shows the situation when teacher explained about analytical and hortatory exposition then asked to the student by saying "what's the different?" then one student respond it by answering the difference._Based on the situation above, the function of the expression was to ask the students to mention the different of the text.

\section{9) Farewell}

This expression is the last types of expression that teacher used in the classroom. Usually teacher uses this expression in the ending of the teaching and learning process as a closing of the meeting as following extracts:

\section{$\underline{\text { Extract }}$}

T: iyya bisa diprint. Okay? Understood? Okay. I think it is over for this time. Thank you. See you next meeting.

Data Display:

\begin{tabular}{|l|l|l|l|}
\hline $\begin{array}{l}\text { Teacher's expression } \\
\text { (extract) }\end{array}$ & Function & Type of expression & Aim/Purpose \\
\hline $\begin{array}{l}\text { See you next } \\
\text { meeting }\end{array}$ & $\begin{array}{l}\text { To close the } \\
\text { meeting }\end{array}$ & Farewells & $\begin{array}{l}\text { The students get } \\
\text { ready to finish } \\
\text { the learning } \\
\text { process }\end{array}$ \\
\hline
\end{tabular}


Analysis of extract:

The extract above shows the teacher's expression at the last of teaching and learning process by saying "See you next meeting".In this situation, this expression also has one function which is to close the meeting by hoping there will be next meeting between teacher and student.

\section{Frequency of Expressions Uttered by the Teachers}

\begin{tabular}{|c|c|c|c|c|c|c|c|c|c|c|}
\hline $\begin{array}{l}\underbrace{\infty}_{0} \\
\sum_{\Sigma}^{\infty}\end{array}$ & 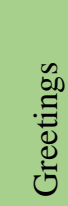 & 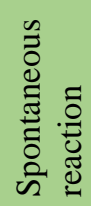 & 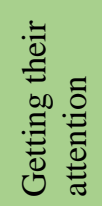 & 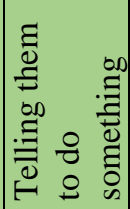 & 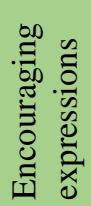 & 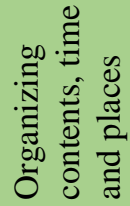 & 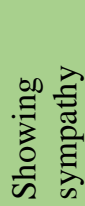 & 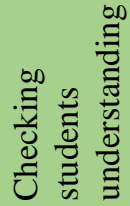 & 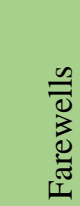 & 䒿 \\
\hline $1^{\text {st }}$ meeting & 1 & 2 & 8 & 38 & 5 & 9 & 0 & 22 & 1 & 86 \\
\hline $2^{\text {nd }}$ meeting & 1 & 2 & 8 & 26 & 0 & 3 & 0 & 17 & 1 & 58 \\
\hline $3^{\text {rd }}$ meeting & 2 & 1 & 2 & 16 & 2 & 5 & 1 & 16 & 0 & 45 \\
\hline $4^{\text {th }}$ meeting & 2 & 0 & 5 & 30 & 4 & 13 & 0 & 32 & 2 & 88 \\
\hline $5^{\text {th }}$ meeting & 3 & 3 & 8 & 19 & 9 & 11 & 0 & 2 & 2 & 56 \\
\hline $6^{\text {th }}$ meeting & 0 & 1 & 4 & 26 & 7 & 14 & 0 & 8 & 2 & 62 \\
\hline Average & 2.7 & 2.7 & 8.8 & 39.2 & 6.8 & 13.9 & 0.2 & 24.5 & 2.02 & $\begin{array}{l}39 \\
5\end{array}$ \\
\hline
\end{tabular}

The table above represents the frequency of the types of Expressions used by teacher in the data during beginning of the meeting until the ending of the meeting from the classroom recording. The data showed that the most types of Expressions uttered by the recorded of the teachers in teaching English was telling students to do something where from 395 utterances which used expressions, telling them to do something was occurred 155 times (39.2\%). The next was followed by checking students' understanding, it was occurred 97 times $(24.4 \%)$. The third expression was about organizing content, time, and places. This expression was occurred 55 times (13.9\%) during six meetings. The forth expression was getting student's attention, it was occurred 35 times $(8.8 \%)$ during the observation. The fifth expression was encouraging expressions. The data showed, it was occurred 27 times $(6.8 \%)$. The next expression was greetings, it was occurred 9 times $(2.2 \%)$. It was followed by spontaneous reaction that has same times in utterances, it was also occurred 9 times $(2.2 \%)$. The next expression is farewells,. Based on the data, it was occurred only 8 times $(2.02 \%)$. Finally, the least expressions uttered by teacher is showing sympathy, based on the data observation it was occurred once $(0.25 \%)$ only in third meeting.

\section{Student's response toward the teachers' verbal expressions}

The data taken by the researcher during the teaching and learning process from the first meeting until the sixth meeting of two teachers and two classes which were observed. The data for the students' responses were also taken through the interview in two classes of the students. The first class consists of 19 students and the second class consists of 18 
students. Only 30 students followed the interview session. The students' responses classified into positive responses and negative responses (Borich :1996).

On the interview section, the researcher asked some questions that related to the teacher expression based on Alfaro's classifications which are included some point as the following below:

\section{a. Greetings}

The researcher asked the students about how they respond and feel when teacher greets them in the class. In this question, the writer asked about what the expressions and how the students respond. All of them said they respond their teachers. Some of them said they are happy has being greets from the teachers and some of them also said they gave response because they respect their teachers. As the following statements:

"senang, karena biasa ada guru langsung masuk tidak ada permulaan jadi kagetki kalau begitu"

\section{b. Spontaneous reactions}

The next questions were about spontaneous reactions. Students said that the teacher uttered spontaneous reaction in the case asking about their body feeling. Based on the interview, all students gave positive responses. All of them said they respond these expressions by answering when the teacher asked them. There were 4 students said they are surprised at the beginning but after that they still respond by answering. They were 15 student said they are happy to be asked because they think it gives meaning that the teacher care about them. As the following statements:

"pertamanya diam karena kaget tapi setelah itu dijawabmi".

However, there were 5 students said that they never been asked about this expression such a statement below:

"tidak pernah kak"

\section{c. Getting their attention}

The researcher asked the student about how they respond when teacher tried to get their attention. Most of them said the teacher used this expression when class was noise and also when the teacher explained something. From 30 studenst, there were 20 gave positive responses. There were 17 students saying they directly gave attention to the teacher when teacher asked them. As the following statement:

"ya tentu sebagai siswa saya mesti menaati apa yang dikatakan guru"

However, there were also some students gave negative response. There were 5 student give response based on their feeling at the time when the teacher asked them. As the following statement:

"tergantung, ketika sedang ngantuk, ya tidak diindahkan tapi kalau lagi bersemangat belajar saya perhatikan langsung”

\section{d. $\quad$ Telling students to do something}

The researcher asked the students about how they respond and feeling when their teacher's asked them to do something. Based on the interview, there were 27 students gave positive response. They responded the utterances by doing the job which is their teachers' gave them. There were 10 student said its' normal for teachers to ask them to do something. 
And there were 12 students said that they respond the teacher's expression because they respect their teacher. Then 5 students said they were happy because they think it gave meaning that the teacher was trust him by asking them to do something. As following extracts:

"yah wajar kalau guru menyuruh siswanya"

"ya tentunya mengerjakan apa yang dikatakan guru karena beliau kan orangtua disekolah"

"tentunya saya senang karena merasa guru percaya kepada saya"

However, there were 3 students gave negative response. They said they ignored what the teacher asked to them. As the following extract:

"kadang-kadang tidak digubris kayak angin berlalu saja"

Besides that, the researcher also asked whether the teacher ever been asked them to do something by yelling or not and how students response and feeling about that. From 30 students, only 5 students said that teacher ever asked them by yelling. They said they feel scared and still did what the teacher's asked because they assumed that when the teacher yelled, it gave meaning that the teacher in anger. As following extract:

"yah langsung diam karena suara keras kan seakan-akan kesannya marah"

\section{e. Encouraging expressions}

The next point is about encouraging expression. The researcher asked about how they feel and respond when teacher gave encouraging expressions. Most of the students said that the teacher always give encouraging expression to student when student success to do assignment in the class. All of them said they gave positive response and also feeling happy if the teacher gave them encouraging expressions. Besides that, they also feel more confidence, proud and excited if the teacher gave encouraging expression to them. As the following statements:

"pastinya excited"

"I feel so happy"

\section{f. $\quad$ Organizing content, time and places}

Another expression is about organizing content, time and places. The researcher asked the students about their response about organizing, time, and places expressions used by teachers' in the classroom. All of them said they gave positive response by answering and doing what the teacher's asked to them. As the following statements:

"pastinya dipatuhi"

\section{g. Showing sympathy}

The next expression was about showing sympathy. The researcher asked students about their response when teacher uttered expression in showing sympathy to their student. From 30 students, all of student gave positive response. They said it can increased their motivation in studying and also some of them said they felt happy if the teachers were showing sympathy to them as following extracts:

"kami kalau dikasi dukungan tentunya merasa semangat" 
ELT Worldwide Vol. 4 No. 1 (2017)

\section{h. Checking student's understanding}

The next point was about checking students understanding. The researcher asked about how the students responded when the teacher checked their understanding in the class. The data showed, all of students gave positive response to their teacher. There were 8 student said they would respond their teacher even they understand or not by answering, such as if they didn't understand they will give feedback to teacher by asking about what they didn't know. As following statements:

"saya jawab tapi kalau saya tidak paham, saya jawab bilang saya tidak paham"

"pastinya bilang mengerti kalau dimengerti, kalau tidak, kami akan bertanya lagi dan lagi"

\section{i. Farewells}

The last expression was farewells. The researcher asked the students about how they responded if the teacher said something as farewells at the ending of meeting in the classroom. They said most teacher said "assalamualaikum warahmatullahi wabarakatuh" as a kind of farewells expression. Based on the interview, all of students gave positive response. They said they responded by answering their teacher before they would left the room. As following statements:

"dijawab see you mam. Waalaikumsalam"

\section{DISCUSSIONS}

The aims of this study were to find out the types and function of English expressions uttered by the teachers, what the dominant types of expressions used by the teachers and what the student's response toward teacher's expressions in EFL classroom.

\section{Types and function of the expressions used by the teacher's}

Based on the findings there were nine kinds of verbal expression uttered by the teacher in teaching and learning process in EFL classroom which based on Alfaro's classifications (2009). Those kinds are presented as follows:

\section{a. Greetings}

The first expressions called greetings (Alfaro: 2009). The data was collected through observation and video recordings in EFL classroom. This expressions also was mentioned in a book by Kistono et al.(2006), Wardiman et al. (2008). Greetings are important as well as frequent in everyday social interactions such as between teacher and students in the classroom. This expression used at the beginning of the classroom when teacher was already come to the class as in.

\section{b. $\quad$ Spontaneous reactions}

The second expressions called spontaneous reactions (Alfaro:2009). The data was collected through observation and video recordings in EFL classroom. This expression used such as when teacher congrats the student, say thanking, apologizing and asking something to students. Thanking, apologizing and congratulating were mentioned also as one of expressions in a book about English expressions by Kistono et al.(2006), Wardiman et al. (2008). Based on the data showed, the teacher mostly uttered this expression when teacher want to know and check the feeling or body condition of their student during the process of learning in the classroom as a caring of teacher to the student. 


\section{c. Getting student's attention}

Based on Alfaro's classifications, the third expression that used by teacher in the classroom is getting student's attention. The data was collected through observation and video recordings in EFL classroom. Teachers have to conscious about the situation in the classroom, teacher needs to monitor and control the student in the classroom continuously in order to get the effective teaching and learning process but teacher also has to realize how and when the students must be controlled in order to avoid authorization in the classroom.

\section{d. $\quad$ Telling students to do something}

The forth expression that uttered by the teacher was telling student to do something (Alvaro:2009). This expression also mentioned by Kistono et al.(2006), Wardiman et al. (2008) in their books about English expressions. The data was collected through observation and video recordings in EFL classroom. During teaching and learning process, teacher usually ask student to do something in many. In asking student to do something, unfortunately sometimes teacher doesn't realize that teacher asking by yelling. According to David Thomas essay, "The Mind of Man" states, "children who are yelled at feel rejected and frightened because a teacher shouts at them" (Thomas 122). The example above demonstrates the feelings of the student towards the teacher's behavior that block the students from learning. Sometimes teacher did not recognize that yelled is not solution for the student.

\section{e. Encouraging expressions}

The fifth expressions called encouraging expressions (Alfaro: 2009). The data was collected through observation and video recordings in EFL classroom. In teaching and learning process, teacher needs to use encourage expression in order to student feel more be valued and respected to do something in the classroom. The utterances which were shows the encouraging expressions used in command and compliment to the students.

\section{f. $\quad$ Organizing contents, time and places}

The next expressions that is used by teacher is about organizing, time and places (Alfaro:2009). The data was collected through observation and video recordings in EFL classroom. During the teaching and learning process, the teacher needs to organize about the content, time and places in the classroom. In order that, what the teacher's willing about effective teaching and learning process can be reached.

\section{g. $\quad$ Showing sympathy}

The next expression is about showing sympathy (Alfaro:2009). The data was collected through observation and video recordings in EFL classroom. Showing sympathy is needed for student in interaction between teacher and student during teaching and learning process in order to create positive atmosphere in the classroom. In the extract showed the situation when students have mispronounce of the word, teacher express her sympathy by give student chance to try again in pronouncing the word correctly by following their friend who has pronounced well .

\section{h. Checking students understanding}

The eighth expression is about checking student understanding (Alfaro:2009). The data was collected through observation and video recordings in EFL classroom. 
Checking students understanding is very crucial things to do for the teacher so that the teacher can know how the understanding of student in the material which is taught by teacher. As long as the process of teaching and learning, checking students understanding must be always to do. In checking students understanding, teacher can do in some ways, like asking, reviewing, and confirmation the content of the material to the students.

\section{i. $\quad$ Farewells}

The last expression is expression about farewells (Alfaro:2009). The data was collected through observation and video recordings in EFL classroom. In the extracts showed two kinds of farewells expression that were uttered by the teachers. The first, she said "take care ya" to the student, as a message for students before leave the classroom. The second, she said "assalamualaikum warahmatullahi wabarakatuh" to close the meeting, as in first expression "greeting", she used it in starting the meeting.

\section{Frequency of expressions uttered by the teachers}

It was found in the finding that the most dominant types of expressions uttered by the teacher during the observation were telling them to do something. It was occurred 155 times during sixth meeting. In this case, teacher mostly used expressions that asking student in doing something in the class. Because based on the extracts, as a teacher there are many things that can be asked to the student in relation with effectiveness of teaching and learning process. The second expression was checking student's understanding, it is occurred 97 times from the first meeting until the sixth meeting. Properly, checking students understanding become the second expression that dominant used by teacher because it is became a must to know whether student understand or not such as about teacher's explanation or the material that has given to them. The third expression is about organizing content, time, and places. This expression was occurred 55 times during six meeting. Most of this expression uttered when the teacher organizes the contents of class whether about organizing the students or the material during the teaching and learning process.

The forth expression was getting student's attention, it was occurred 35 times during the observation. Based on the observation, the teacher uttered this expression when the students got noisy. The fifth expression that dominant uttered by teacher was encouraging expressions. The data showed, it was occurred 27 times, the teacher use this expression to give a reward for student who do the best in presentation or doing assignment. The next expression is greetings, it was occurred 9 times. The teacher used this expression at beginning of the class when teacher and student were already come and meet in the class. The seventh expression is about spontaneous reaction, it was also occurred 9 times. The next expression was farewells. Based on the data, it was occurred only 8 times in the end of the teaching and learning process during six times meeting.. The last expression that has at least times to use by teacher was showing sympathy, based on the data observation it was occurred for once only in third meeting. By using this expression, teacher tried to motivate the student but based on the extract showed that the teacher was more inclined use encouraging expression in motivate student than used expressions about showing sympathy. 


\section{Students' responses toward the teacher expressions}

In the previous, the findings of the research showed that for the first expression, all of student gave positive response. They said that they feel happy if the teacher came to the class and greets them. The second expression was about spontaneous reactions, the data from interview showed that all students also gave positive response. Based on the data from interview, the student said in uttered spontaneous reaction, the teacher asked mostly about their condition and feeling during the teaching and learning process. Some of them said they feel surprised but happy because they think teachers care about them. The third expression is getting student's attention, some of the students gave positive response and the other gave negative response. For the student who gave positive response said that they conscious about their position as a student so they have to listen want teacher said and asked to them, and for the students who gave negative response said they response their teacher based on their feeling at the time, if they fell excited at the time, they would give positive response but if they feel bored in the class, they would ignore their teacher.

The next expression was about telling student's to do something, the data showed some students gave positive response and the other gave negative response. The students who gave positive response said that they always do what teacher ask because they respect their teacher, some of them also said they happy if teacher ask them to do something because it means teacher trust on them. While, the students who gave negative response said sometimes they ignore their teacher. Besides that, the writer also asked whether teacher ever been asked them to do something by yelling or not and how students response and feeling about that. Most of them said, they were scare because in their opinion, yelling means anger.

The fifth expressions are encouraging expressions, based on the finding showed that all of student gave positive response to their teacher. They felt happy and confidence in the classroom if teacher encourage them. The sixth expression is about organizing content, time, and places. The data showed, all of student also gave positive response by answering and doing what the teacher's asked to them. The next expressions are showing sympathy, all of student absolutely gave positive response when teacher show sympathy to them. They said they feel happy and it can increase their motivation in studying. The next point is expressions that uttered by teacher about checking students understanding, based on the data showed that all of teacher gave positive response. If they understand, they will answer what teacher ask, then if they don't understand, they will ask and tell teacher what part of the material they don't understand. The last expression is expressions of farewells, based on the interview, all of students gave positive respond. They said they always answered their teacher's farewells expressions.

\section{CONCLUSION AND SUGGESTION}

\section{Conclusions}

Based on the findings and the discussion, the research puts the conlusion of this research : 1) The result of the study showed that the teachers use expressions in their teaching process and they employed many types of expression that each expression has each function. 2) From the result of data analysis, it was also found that the teachers filled all the types of expression based on Alfaro's classifications. 
On the other hand, the most dominant expressions were telling students to do something. 3) The study also reveals about learners' responses toward the teachers' expression. The data revealed that, the learners' responses toward the teachers 'expressions categorized into 9 commonly expressions used by the teachers. Most of the students gave positive response in all the expressions but some of them also gave negative response.

\section{Suggestions}

Referring to the findings and conclusion presented as previously, the researcher suggests the following suggestions: 1) The English teacher should consider in utterances expressions in the classroom. The teacher should pay attention on the student's response, so that the teacher can consider about their expression that they utter then the students can give response correctly. 2) In the future, the researcher expects that there should be more researches in relation with verbal expression in the English classroom. So it will be more interesting to investigate deeply about the expressions. Because in this research do not discuss about the effect of teacher's expression with the goal of the learning, so Further researcher may investigate about the effect of teacher's expressions on students goal. It would be also interesting to study about correlation of the teacher expression in grammatically and comprehensibility to the students.

\section{REFERENCES}

Akram, M. 2008. Speech Acts : A Constrative Study of Speech Acts in Urdu and English. ASIAN EFL Journal Vol 10 no 42008.

Alfaro, David.2009. Everyday English Expressions in Class. XORNADAS CLIL: Integrando linguas "a través" do currículo - CFR VIGO. [Online] Available : www.edu.xunta.es/centros/.../expressions.pdf.everydayEnglish expressions in class. Accessed on 2015-08-08.

Allwright, D. M. B. 1991. Focus on the Language Classroom. An Introduction to Classroom Research for Language Teachers.Cambridge: Cambridge University Press..

Borich, D.G.1996. Effective Teaching Methods. Englewood Cliffs, N.j: Merril.

Downing, James. 1992. Effects of Repeated Expressions on Attitude Extremity. Journal of Personality and Social Psychology 1992. Vol. 63. No. 1.17-29. Copyright 1992 by the American Psychological Association, Inc. 0022-3514/92/S3.00. University of Kansas:Kansas. .

Gay, Mills, and Airasian. 2006. Educational Research: Competencies for Analysis and Application (Eighth Edition). United States of America. Pearson Prentice Hall, Inc.

Heidegger, Martin. Phenomenology of Intuition and Expression: Theory of Philosophical Concept Formation (English). Publisher: Continuum International Publishing Group Ltd.

Lauder, A. 2008. The Status and Function of English in Indonesia; a review of the factors. MAKARA, Social Humaniora, 12:1, 9-20

Lörscher, W. 1986. Conversational Structures in the Foreign Language Classroom. In Gabriele Kasper (ed.). Learning, Teaching and Communication in the Foreign Language Classroom. Aarhus: Aarhus University Press. 11-22. 
Milligan, John, P. Motivation of English Expression. Vol. 19, No. 1 (January 1942), pp. 57, 37. Published by: National Council of Teachers of English.

Muhayyang, Maemuna.2010. Lecturer and student talk in Classroom Interaction: A classroom Management Scheme. Makassar: Program Pasca Sarjana Universitas Hasanuddin Makassar.

Sugiono.2009. Metode Penelitian Pendidikan. Alfabeta Bandung.

Thornbury, Scott. Teachers research teacher talk. ELT Journal Volume 50/4 October 1996 .Oxford University Press 1996

Wastika. 2013. The use of English expressions in RSBI of SMPN 12 Makassar. Makassar: Program Pasca Sarjana Universitas Negeri Makassar

Yosida, Etsuko. 2011. Referring expressions in English and Japanese. John Benjamins Publishing. 